\title{
Towards Effective Military Training in International Humanitarian Law
}

\author{
Elizabeth Stubbins Bates*
}

This article is forthcoming in the International Review of the Red Cross (special issue on Generating Respect for the Law) Volume 96, Number 895/896, 2015

\begin{abstract}
The obligation to train troops in international humanitarian law (IHL) is simply stated and its implementation delegated to state discretion. This reflects a past assumption that mere dissemination of IHL would be an effective contribution to the prevention of violations. Academic literature has evolved, so that dissemination alone is known to be insufficient for compliance; while the ICRC's integration model emphasizes the relevance of IHL to all aspects of military decision-making. A separate process, the ICRC/Government of Switzerland Initiative on Strengthening Compliance with IHL, is still in its consultative stages at the time of writing, but may result in voluntary state reporting and/or thematic discussions at meetings of States. This article synthesizes academic and practitioner insights on effective IHL training, and suggests a collaborative rubric for informative, standardized reporting on IHL training. Such a rubric could enable states and researchers to share best practice and future innovations on IHL training, using a streamlined, cost-effective tool.
\end{abstract}

Keywords: Compliance, Dissemination, ICRC, Integration, International Humanitarian Law, IHL, Law of Armed Conflict, LOAC, Military Training, Social Psychology

\section{Introduction}

The treaty obligation to integrate international humanitarian law (IHL) in programmes of military instruction and training is a component of the broader duty to disseminate IHL "as widely as possible", including to the civilian population. ${ }^{1}$ Despite its applicability in peace

\footnotetext{
* $\mathrm{PhD}$ Candidate (AHRC funded), SOAS, University of London; the author acknowledges valuable feedback from the American Society of International Law Research Forum in October 2012, the Society of Legal Scholars UK Conference in September 2013, the SOAS School of Law PhD Colloquium in January 2014; and is grateful to Iain Scobbie of the University of Manchester, Andrew Bell of Duke University and anonymous reviewers for their helpful comments on earlier drafts. All errors remain the author's own.

${ }^{1}$ Geneva Convention for the Amelioration of the Condition of the Wounded and Sick in Armed Forces in the Field of 12 August 1949, 75 UNTS 31 (entered into force 21 October 1950)(GC I), Art. 47; Geneva Convention for the Amelioration of the Condition of Wounded, Sick and Shipwrecked Members of Armed Forces at Sea of 12 August 1949, 75 UNTS 85 (entered into force 21 October 1950) (GC II), Art. 48; Geneva Convention Relative to the Treatment of Prisoners of War of 12 August 1949, 75 UNTS 135 (entered into force 21 October 1950)(GC III), Art. 127; Geneva Convention Relative to the Protection of Civilian Persons in Time of War of 12 August 1949, 75 UNTS 287 (entered into force 21 October 1950) (GC IV), Art. 144; Hague Convention for the Protection of Cultural Property in the event of Armed Conflict, 14 May 1954, 249 UNTS 240 (entered into force 7 August 1956), Art. 25; Protocol Additional to the Geneva Conventions of 12 August 1949, and Relating to the Protection of Victims of International Armed Conflicts, 8 June 1977, 1125 UNTS 3 (entered into force 7 December 1978) (AP I), Arts 83, 87(2); Convention on Prohibitions or Restrictions on the Use of Certain
} 
and war, in treaties and customary international law, and (with some differences in specificity as between treaty and custom) to international and non-international armed conflict, ${ }^{2}$ the IHL training obligation is simply stated and discretionary, with only recent treaties and soft law adding detail on how it should be implemented. ${ }^{3}$ The simplicity of the treaty norm reflects an historic assumption that dissemination and training were necessary (though perhaps insufficient) to ensure compliance with IHL. The Pictet Commentaries to these training provisions saw them as logically prior to the duty to "respect and ensure respect" for the Geneva Conventions of 1949 "in all circumstances". ${ }^{4}$ At the Diplomatic Conference of Geneva 1974-1977, ICRC and state representatives spoke of dissemination and training's capacity to promote compliance for IHL: ${ }^{5}$ an idealistic assumption which grounded the diplomatic debates, but which was not tested by research or empirical data.

Subsequently, the scholarly consensus has become pragmatic and cognisant of the limitations of IHL training to prevent violations: military IHL training should aim to internalize norms through attitudinal change, discourse and repetition, yet training is acknowledged to be insufficient to ensure compliance with the law. ${ }^{6}$ In the past decade in particular, the literature has benefited from interdisciplinary insights. IHL training needs to take place in a context which facilitates the development of conscience: with input from education theory, ${ }^{7}$ social and organisational psychology, ${ }^{8}$ and perhaps military ethics. ${ }^{9} \mathrm{~A}$

Conventional Weapons which may be deemed to be Excessively Injurious or to have Indiscriminate Effects, 10 October 1980, 1342 UNTS 137 (entered into force 2 December 1983),(CCW)1980, Art. 6; Second Protocol to the Hague Convention of 1954 for the Protection of Cultural Property in the event of Armed Conflict, 26 March 1999, 2253 UNTS 212 (entered into force 9 March 2004), Art. 30.

${ }^{2}$ Protocol Additional to the Geneva Conventions of 12 August 1949, and Relating to the Protection of Victims of Non-International Armed Conflicts, 8 June 1977, 1125 UNTS 609 (entered into force 7 December 1978) (AP II), Art. 19; Yves Sandoz, Christopher Swinarski \& Bruno Zimmermann (eds), Commentary on the Additional Protocols of 8 June 1977 to the Geneva Conventions of 12 August 1949, ICRC, Geneva, p.1489, para. 4912; Jean-Marie Henckaerts \& Louise Doswald-Beck, Customary International Humanitarian Law, ICRC, Cambridge University Press, Cambridge, 2005 (ICRC Customary IHL Study), Rule 142; Second Protocol to the Hague Convention of 1954 for the Protection of Cultural Property in the event of Armed Conflict 1999, above note 1 , Art. 30.

${ }^{3} \mathrm{CCW}$, above note 1, Art. 6; Amended Protocol II, Art. 14(3); Second Protocol to the Hague Convention 1954, above note 1, Art. 30; ICRC and Swiss Federal Department of Foreign Affairs, Montreux Document on Pertinent Legal Obligations and Good Practices for States related to Operations of Private Military and Security Companies during Armed Conflict, 2008, (Montreux Document), Good Practices 3(a), 10, 14 (e), 35 , 63.

${ }^{4}$ GC I, Art. 1; GC II, Art. 1; GC III, Art. 1; GC IV, Art. 1, above note 1 (Common Article 1); Jean Pictet (ed.), Commentary to the Four Geneva Conventions of 12 August 1949, Vol. I, 1952, pp.347-349, Vol. II, 1960, pp. 257-259, Vol. III, 1960, pp.613-615, Vol. IV, 1958, pp.580-582. Editor's note: Revised versions of the Commentaries on the Geneva Conventions and their Additional Protocols are currently forthcoming. The revised Commentary on GC I is expected to be published in 2015.

${ }^{5}$ Official Records of the Diplomatic Conference of Geneva 1974-1977, Volume IX, Summary Records, Third Session of Committee I, 59th Meeting, 17 May 1976 (CDDH/I/SR.59) pp.241-244, draft Art. 37 of AP II Dissemination, CDDH/1, CDDH/226.Corr.2.

${ }^{6}$ Françoise Hampson, "Fighting by the Rules: Instructing the Armed Forces in Humanitarian Law", International Review of the Red Cross, Vol. 29, Issue. 269, April 1989, pp.111-124; Marco Sassòli, "The Implementation of International Humanitarian Law: Current and Inherent Challenges" Yearbook of International Humanitarian Law, Vol. 10, 2007, pp. 45-73.

${ }^{7}$ Jenny Kuper, Military Training and Children in Armed Conflict: Law, Policy and Practice, Martinus Nijhoff, The Hague, 2005, pp.173-4

${ }^{8}$ Albert Bandura, "Moral Disengagement in the Perpetration of Inhumanities" Personality and Social Psychology Review, Vol. 3, No. 3, 1999, 193-209; Laura Dickinson, "Military Lawyers on the Battlefield: An Empirical Account of International Law Compliance" American Journal of International Law, Vol. 104, No. 1, 2010, pp.1-29.

${ }^{9}$ M. Sassòli, above note 6, p.73; Paul Robinson, Nigel de Lee and Don Carrick (eds), Ethics Education in the Military, Ashgate, Aldershot, 2008; Martin L. Cook and Henrik Syse, "What Should We Mean by Military 
decade ago, the ICRC's first Roots of Behaviour in War Study showed that knowledge of the law and attitudes consistent with a risk of violations can occur together. This finding creates a conundrum between IHL training and compliance. ${ }^{10}$ The Roots of Behaviour in War Study will be reviewed and updated in newly-commissioned work. ${ }^{11}$ Historical reflection and social psychology shows that the aims of basic training (desensitisation, breaking down a soldier's inculcated reluctance to kill, unit cohesion and obedience to the command chain) are antagonistic to many of the aims of IHL training. ${ }^{12}$ There is a conundrum, possibly a paradox, between IHL training and compliance.

The ICRC's practice has evolved as the academic research has broadened. It has moved from an emphasis on dissemination of IHL norms to States and non-State armed groups, to integration - the idea expressed in 2007 that IHL should be included into all aspects of "doctrine, training, education, equipment and sanctions", ${ }^{13}$ and more recently in 2011, that IHL is continuously relevant to the decision-making and communication within the military command structure. ${ }^{14}$ These principles remain a work-in-progress and have not to date been tested empirically.

In a separate development, the ICRC and the Government of Switzerland are leading a major consultative process on Strengthening Compliance with International Humanitarian Law, established inter alia "to enhance and ensure the effectiveness of mechanisms of compliance with international humanitarian law". ${ }^{15}$ This process is still in its consultative stages at the time of writing, but may lead to voluntary state reporting and/or thematic discussions at meetings of States.

This article charts the simply stated, discretionary obligation on States to train troops in IHL; and the conundrum between training and subsequent compliance, with reference to academic and practitioner literature and interdisciplinary work. Then it explores the ICRC's evolution from dissemination to integration, and the organization's broader work on preventing violations of IHL. Synthesizing these separate, interstitial developments adds substantive depth to effective IHL training: in brief, training that contributes to compliance on operations and helps to prevent violations. If the Strengthening Compliance Initiative does support voluntary state reporting or separate thematic discussions on the domestic implementation of IHL in general, then the article recommends a collaborative rubric for reporting on IHL training specifically. Such a rubric could enable states and researchers to share best practice and future innovations on IHL training, using a streamlined, cost-effective

Ethics?" Journal of Military Ethics, Vol. 9, No. 2, 2010, pp. 119-122; David W. Lovell, "Educating for Ethical Behaviour? Preparing Military Leaders for Ethical Challenges" in David W. Lovell and Igor Primoratz (eds), Protecting Civilians During Violent Conflict: Theoretical and Practical Issues for the 21 st Century Military and Defence Ethics series, Ashgate, Aldershot, 2012 p.141.

${ }^{10}$ Daniel Muñoz-Rojas and Jean-Jacques Frésard, "The Roots of Behaviour in War: Understanding and Preventing IHL Violations" International Review of the Red Cross, Vol. 86, No. 853, 2004, pp.189-206.

11 ICRC, "Roots of Behaviour in War: Revisited", 3 November 2014, available at: https://www.icrc.org/eng/war-and-law/law-and-policy/articles/rbw.htm.

12 Richard Holmes, Acts of War: The Behaviour of Men in Battle, Cassell, London, 2003 (first published 1983); Ben Shalit, The Psychology of Conflict and Combat, Praeger, New York, NY, 1988; Joanna Bourke, An Intimate History of Killing: Face-to-Face Killing in Twentieth Century Warfare, Granta, London, 1999.

13 ICRC, "Integrating the Law", 8 June 2007, Publication Ref 0900, available at: http://www.icrc.org/eng/resources/documents/publication/p0900.htm (all Internet references were last visited in June 2015); ICRC, "Violence and the Use of Force", 2011, p.58.

${ }^{14}$ ICRC, "Decision-making Process in Military Combat Operations", Publication Ref 4120, December 2013.

${ }^{15}$ Resolution $1,31^{\text {st }}$ International Conference of the Red Cross and Red Crescent, 2011, at: https://www.icrc.org/end/resources/documents/resolution/31-international-conference-resolution-1-2011.htm. 
tool. Finally, the article offers some next steps for interdisciplinary research on effective IHL training, and then concludes.

\section{The Obligation to Disseminate IHL and to Integrate it into Military Instruction and Training}

IHL's earliest documents refer to dissemination of a then-novel set of norms, and to the assumption that spreading awareness of IHL among all citizens would prevent unlawful conduct by citizen soldiers. The Oxford Manual of War on Land 1880 is one such example, ${ }^{16}$ reflecting the recommendation from the Second International Conference of the Red Cross in Berlin in 1869 that knowledge of the First Geneva Convention be publicized as much as possible, especially among soldiers. ${ }^{17}$ "[N]ecessary steps" must be taken to instruct troops and disseminate IHL treaty law under Article 26 of the Geneva Convention of $1906,{ }^{18}$ while Article 1 of Hague Convention IV 1907 included an obligation to "issue instructions" (orders, not education) to troops which were consistent with the Convention and its annexed regulations. The Four Geneva Conventions of 1949 require States to disseminate IHL "as widely as possible", and "in particular" to integrate IHL study into programmes of military instruction. ${ }^{19}$ Yet these dual dissemination and training norms are merely stated: with minimal guidance to States on how best to train soldiers and officers in IHL. It may be true, as per the ICRC Commentary, that dissemination and military instruction are logically prior to the obligation in Common Article 1, to "respect and ensure respect" for Geneva law "in all circumstances", but a simple norm, delegated to State discretion, is not ideally crafted for the prevention of violations ${ }^{20}$

Where ratified, Additional Protocol I adds substance to the obligation, but still leaves the IHL training obligation delegated to State discretion, and delegated again to those officers who, once trained in IHL, will themselves train the soldiers under their command (a "train the trainers" model which requires further testing as to its effectiveness). Article 6(1) of Additional Protocol I requires High Contracting Parties to "train qualified personnel to facilitate the application of the Conventions and of this Protocol..." Article 82 specifies the role of legal advisers, while Article 87 sets out the duties of commanders, which include an obligation to "ensure that members of the armed forces under their command are aware of their obligations" under Geneva law. ${ }^{21}$ Article 83 requires that "[a]ny military or civilian authorities who ... assume responsibilities in respect of the application of the Conventions

\footnotetext{
${ }^{16}$ The Oxford Manual on the Laws of War on Land, Preface (Institute of International Law, 1880), cited in François Sénéchaud, "Instructing the Law of Armed Conflict: A Review of ICRC Practice" Israel Defense Forces Law Review, Vol. 3, 2007, 49.

${ }^{17}$ IIème Conférence international des gouvernements signataires de la Convention de Genève et des Sociétés et associations de secours aux militaires blesses et malades, Imprimerie J.F. Starcke, Berlin, 22-27 April 1869, cited in Vincent Bernard, "The ICRC's Evolving Experience in Prevention", 36th Round Table on Current Issues in International Humanitarian Law, San Remo, 3-5 September 2013, available at: http://www.iihl.org/Media/Default/Round\%20Tables/XXXVI\%20Round\%20Table/Speakers\%20contributions/ Bernard_Final.pdf.

${ }^{18}$ Convention for the Amelioration of the Condition of the Wounded and Sick in Armies in the Field, Geneva, 6 July 1906 (entered into force 9 August 1907).

${ }^{19}$ GC I, Article 47; GC II, Article 48; GC III, Article 127; GC IV, Article 144; above note 1.

${ }^{20}$ Common Article 1; J. Pictet (ed.) Commentary, above note 4, pp.384, 257, 613-4, 580.

${ }^{21}$ AP I, Art. 87(2).
} 
and this Protocol ... shall be fully acquainted with [their] text."22 These are obligations of result: they do not give guidance to States on how to achieve that result.

The IHL training obligation is clearly delegated to state discretion: The ICRC Commentary to Article 83 of Additional Protocol I emphasizes that the "...setting up the programme [of military instruction]... will probably require decisions at a ministerial level..." ${ }^{23}$ In Resolution 21 of the Diplomatic Conference of Geneva 1974-1977, States are "invite[d]" to "encourag[e]...the authorities concerned to plan and to give effect" to IHL training, with ICRC assistance if necessary, "in a manner suited to national circumstances". ${ }^{24}$ Article 25 of the Hague Convention for the Protection of Cultural Property 1954, and Article 6 of the Convention on Certain Conventional Weapons contain similarly drafted provisions. ${ }^{25}$ Discretion is not surprising. As Peter Rowe notes, "It is in the very nature of international law that a state may decide for itself how its obligations may apply in the sphere of its own municipal law". ${ }^{26}$ It could be because of state sovereignty and because IHL dissemination and training obligations persist in peace and war that these provisions were drafted so simply and with flexibility. Nonetheless, delegation and discretion raise questions as to the effectiveness of the IHL training obligation in promoting compliance with the law.

A draft third paragraph in what became Article 83 of Additional Protocol I would have provided for the evaluation of States' IHL dissemination and training obligations through periodic reporting every four years. Following objections from the USSR and 16 other States in Committee $\mathrm{I},{ }^{27}$ this provision was narrowly approved but later rejected in the plenary conference.

These simply stated, discretionary norms also show the durability of the assumption that dissemination would contribute to IHL compliance. At the Diplomatic Conference of Geneva in 1974-1977, ICRC and State representatives asserted a causal relationship between dissemination of IHL and prevention of violations. In detailed debate on the proposed dissemination and training obligation in what was then draft Article 37 of Additional Protocol II, Mrs Junod of the ICRC argued that dissemination is "one of the most important" "measures suitable for strengthening the existing law"; ${ }^{28}$ while Mr Grandison, the delegate from the USA, believed dissemination and instruction is "one of the most effective means of securing compliance with humanitarian law". This assumption establishes a delegation's commitment to IHL compliance and to obligations which might facilitate it, but it remains an assumption. Academic research and the ICRC's integration theory show a more intricate approach to causation and compliance.

The lengthy debate on draft Article 37 of Additional Protocol II was largely wasted, as the phrasing from the committee stage which would have provided for an obligation to

\footnotetext{
${ }^{22}$ AP I, Art. 83(2).

${ }^{23}$ Y. Sandoz, C. Swinarski and B. Zimmermann (eds), Commentary on the Additional Protocols, above note 2 , p. 963 , para. 3375 .

${ }^{24}$ Diplomatic Conference of Geneva 1947-1977, Resolution 21, Dissemination of Knowledge of International Humanitarian Law Applicable in Armed Conflicts, para. 2(a).

${ }^{25}$ Hague Convention for the Protection of Cultural Property in the event of Armed Conflict, above note 1, Art. 25; CCW, above note 1, Art. 6.

${ }^{26}$ Peter Rowe, "The United Kingdom Position", in Hazel Fox \& Michael Meyer (eds), Effecting Compliance: Armed Conflict and the New Law, Vol. II BIICL, London 1993, p. 203.

${ }^{27}$ Official Records of the Diplomatic Conference of Geneva 1974-1977, Volume X, Second Session, Committee I, paras 133-135.

${ }^{28}$ Official Records of the Diplomatic Conference of Geneva 1974-1977, Volume IX, 59 ${ }^{\text {th }}$ Meeting, above note 5 , para. 29.
} 
instruct the armed forces in the IHL of non-international armed conflict was removed in the radically shortened compromise text proposed by Pakistan. ${ }^{29}$ Pakistan's simplified text for Additional Protocol II was drafted to overcome an impasse, with some delegates having stated informally that they would vote against the lengthy draft Protocol if it came to a vote. There is no evidence of a deliberate choice to remove the obligation to train troops in IHL from the renumbered Article 19, which provides simply that States must "disseminate" its text. Nor is there evidence in the archives of a specific objection having been raised to military training in the IHL of non-international armed conflict, in contrast to the widespread objection to the comprehensive nature of the targeting norms in the draft text. The model of delegation continues, because Article 19's "choice of means is left to the Contracting Party or to the parties to the conflict..." ${ }^{30}$ Nonetheless, the ICRC Commentary to Article 19 goes some way towards mitigating the harm caused by the radically shortened text. It explains that soldiers need to be taught "exactly the same behaviour" for international and noninternational armed conflicts alike. ${ }^{31}$

Article 19 of Additional Protocol II is not the last word on whether or not there is an obligation to integrate the IHL of non-international armed conflict into military instruction. Although there is no enumerated IHL training obligation in Common Article 3 to the Four Geneva Conventions, which regulates non-international armed conflicts where Additional Protocol II has not been ratified or does not apply, as Common Article 3 forms part of the whole of the Four Geneva Conventions text, it can be assumed that dissemination and training should include Common Article 3. Amended Protocol II to the Convention on Certain Conventional Weapons also includes an IHL training obligation, as does the Second Protocol to the Hague Convention on Cultural Property. ${ }^{32}$ The ICRC Customary International Humanitarian Law Study reviewed multiple military manuals and found evidence of an IHL training obligation applicable to international and non-international armed conflicts. In the latter, the training obligation binds both armed forces and armed groups. ${ }^{33}$ States including the UK have criticized the ICRC Customary IHL Study for its reputed deductive method, and for the use of military manuals as a source of state practice, yet the argument that Rule 142 is customary only in international armed conflict ${ }^{34}$ is too cautious, and arguably does not reflect current state practice. Leaving customary IHL aside, the outreach to non-State armed groups by non-governmental organizations such as Geneva Call shows that IHL dissemination and compliance activities are becoming more widespread in non-international armed conflicts. ${ }^{35}$

\footnotetext{
${ }^{29}$ Official Records of the Diplomatic Conference of Geneva 1974-1977, 53rd plenary meeting, Fourth Session , p. 151, para. 62, 6 June 1977: "The President drew attention to the proposals by the delegation of Pakistan (CDDH/427 AND Corr.1) to delete Article 37, and replace it by the sentence 'This Protocol shall be disseminated as widely as possible' (CDDH/434). The numbering and positioning of the new simplified article would be dealt with at a later stage.' The simplified text, proposed by the Pakistan delegation (CDDH/434) was adopted by consensus."; Y. Sandoz, C. Swinarski and B. Zimmermann (eds), Commentary on the Additional Protocols, above note 2, p.1488 and footnote 4.

${ }^{30}$ Ibid, p.1488, para.4906.

${ }^{31}$ Ibid, p. 1489, para. 4912.

${ }^{32} \mathrm{CCW}$, above note 1, Amended Protocol II, Art, 14(3); Second Protocol to the Hague Convention 1954, above note 2, Art. 30.

${ }^{33}$ ICRC Customary IHL Study, above note 2, Rules 142, pp.505, 501.

${ }^{34}$ David Turns, "Implementation and Compliance", in Elizabeth Wilmshurst \& Susan Breau (eds), Perspectives on the ICRC Study on Customary International Humanitarian Law, Cambridge University Press, Cambridge, 2007, p.362.

${ }^{35}$ Sandesh Sivakumaran, "Lessons for the law of armed conflict from commitments of armed groups: identification of legitimate targets and prisoners of war", International Review of the Red Cross Vol. 93, No. 882, 2011, pp.463-482; Pascale Bongard and Jonathan Somer, "Monitoring armed non-state actor compliance
} 
More recent treaties and soft law gradually add specificity and guidance to States on how flexibly, or with what expertise, they should implement IHL training. This added specificity from the mid to late 1990s onwards coincides with the gradual evolution by the ICRC from an approach based in dissemination to the early iterations of integration. Amended Protocol II to the Convention on Certain Conventional Weapons 1996, requires "training commensurate with [soldiers'] duties and responsibilities..."; ${ }^{36}$ while Article 30 of the 1999 Second Protocol to the Hague Convention of 1954 provides for co-operation between military and civilian authorities, UNESCO, and non-governmental authorities in dissemination and military instruction in peace and war. In particular, "guidelines and instructions on the protection of cultural property" must form part of military regulations, although not necessarily as part of annual or more frequent training of soldiers or officers. ${ }^{37}$ This quite limited provision is context-specific, but it exemplifies dissemination through multiple actors, not simply an obligation delegated to the state.

The Montreux Document on Pertinent Legal Obligations and Good Practices for States related to Operations of Private Military and Security Companies during Armed Conflict (Montreux Document) usefully expands IHL training and continues the multi-actor emphasis from the Second Protocol to the Hague Convention of 1954. Five of the Good Practices call on States to train PMSC in IHL, often as a precondition for contracts to be concluded between States and those companies. ${ }^{38}$ The Montreux Document is non-binding, and refers only to private military and security companies, so again this detail is contextdependent.

The greater specificity on IHL training in soft law and the Second Protocol to the Hague Convention on Cultural Property is insufficient, given the simply stated, discretionary norm in Geneva law. Questions remain about the empirical effectiveness of States' IHL training programmes: the simplicity of the IHL training obligation creates a conundrum between IHL training and compliance with the law. The next section explores the evolution of academic research on IHL training, and interdisciplinary insights from military ethics and social psychology.

\section{The Conundrum between IHL Training and Compliance}

Modern scholarship on IHL training has evolved from the historic assumption found at the 1974-1977 Diplomatic Conference of Geneva that dissemination and training lead logically to compliance with the law. While the etymology of dissemination might refer to "sowing the seeds" of compliance, ${ }^{39}$ a linguistic root does not equal causation. Academic work on IHL training now recognizes the conundrum between IHL training on the one hand and compliance with IHL on the other. While there is an unquestioned obligation on States (and in non-international armed conflict, on armed groups) to disseminate IHL, research on social psychology in armed conflict questions the causal impact of IHL knowledge on compliance,

\footnotetext{
with humanitarian norms: a look at international mechanisms and the Geneva Call Deed of Commitment", International Review of the Red Cross, Vol. 93, No. 883, 2011, pp.673-706.

${ }^{36} \mathrm{CCW}$, Art.6, above note 1; Amended Protocol II, Art. 14(3).

${ }^{37}$ Second Protocol of the Hague Convention 1954, above note 2, Art. 30(3)(a).

${ }^{38}$ Montreux Document, above note 3, Good Practices 3(a), 10, 14 (e), 35, 63.

${ }^{39}$ Rogier Bartels, "National Red Cross/Red Crescent Societies and International Humanitarian Law" Israeli Defence Force Law Review, Vol. 3, 2007, p. 58, footnote 5.
} 
suggesting that the presence or absence of moral disengagement is more informative. ${ }^{40}$ This research will be re-evaluated one decade on, ${ }^{41}$ and is supported by courts-martial and public inquiries, which suggest ignorance of IHL as one among several contextual factors where atrocities have taken place. ${ }^{42}$ Historical reflection and social psychology shows that the aims of basic training (desensitisation, breaking down a soldier's inculcated reluctance to kill, unit cohesion and obedience to the command chain) are antagonistic to many of the aims of IHL training. ${ }^{43}$ Transcripts of interviews conducted with soldiers involved in the My Lai massacre show the importance of repetition in bayonet drills, to break down soldiers' resistance to kill. ${ }^{44}$ The same interviewee reported that his training did not include the duty not to obey a manifestly unlawful order, and blamed the victims of the massacre for their own fate. This historic and new evidence adds to the insight from Hampson and Sassòli, among others, that IHL training is necessary but insufficient to ensure respect for the law. ${ }^{45}$

\section{Literature on Military Training in IHL}

Earlier literature on IHL training was a mix of academic, empirical and practitioner reflections, and case studies on dissemination in Universities and individual States. ${ }^{46}$ This body of work gives the impression of theory built pragmatically yet interstitially: it hints at but does not fully synthesize the insights from military ethics and social psychology. For example, best practice suggests that training soldiers in IHL should promote attitudinal change ${ }^{47}$ and the "internalisation" of norms so that they become second nature, ${ }^{48}$ but that "barracks culture" and competing priorities can jeopardize effective training. ${ }^{49}$ These sources suggest the importance of educational and behavioural insights, of norm internalisation that echoes constructivist compliance theory, and of group culture and communities of practice. ${ }^{50}$

The educational and behavioural insights form two strands in the research. In the first strand, some works provide checklists for good teaching and instruction. Per Sénéchaud, the instructor should be "convincing", while training should be "integrated", "selective", "simple and continuous", "practical and relevant". ${ }^{51}$ Hays Parks recommends trainers conduct a

\footnotetext{
${ }^{40}$ D. Muñoz-Rojas and J.-J. Frésard, above note 10.

${ }^{41}$ ICRC, "Roots of Behaviour in War: Revisited", above note 11.

${ }^{42}$ William R. Peers, The My Lai Inquiry, Norton, New York, 1979; J. Bourke, above note 12, p.194; cited in Paolo Tripodi, "Understanding Atrocities: What Commanders can do to Prevent them", in D. Whetham (ed.), Ethics, Law and Military Operations Palgrave Macmillan, Basingstoke 2011, 173-188; The Report of the Baha Mousa Inquiry, Vol. III, September 2011, Summary, Part XVIII, p. 1330, para. 294, but contrast p. 1333, para. 310.

${ }^{43}$ R. Holmes, B. Shalit, and J. Bourke, above note 12.

${ }^{44}$ Yorkshire Television, Four Hours in My Lai, Television documentary interview transcripts, Interview with an ex-Sergeant 2nd Platoon,_1988, (originally broadcast 23 May 1989).

${ }^{45}$ F. Hampson, above note 6; M. Sassòli, above note 6.

46 The "Dissemination: spreading knowledge of humanitarian rules" special issue of the International Review of the Red Cross Vol. 37, No. 319, 1997 contains numerous case studies and reflections on IHL dissemination.

${ }^{47}$ Save the Children Sweden, "Behind the Uniform: Training the Military in Child Rights and Child Protection in Africa", 2009.

${ }^{48}$ ICRC Customary IHL Study, above note 2, Rule 142, p.503, footnote 45 (citing the military manual of the Republic of South Africa).

${ }^{49}$ David Lloyd Roberts, "Teaching the Law of Armed Conflict to Armed Forces: Personal Reflections", in Anthony M. Helm (ed.), International Law Studies,Vol. 82, 2006, Naval War College, Newport, Rhode Island, pp.121-134; J. Kuper, above note 7.

${ }^{50}$ Etienne Wenger, Communities of Practice, Cambridge University Press, Cambridge, 1998; Catherine Elgin, Considered Judgment, Princeton University Press, Princeton, NJ, 1999.

${ }^{51} \mathrm{~F}$. Sénéchaud, above note 16.
} 
"terrain appreciation" of the audience for their IHL training, ${ }^{52}$ to ensure that the norms taught are tailored precisely to that audience, and are "commensurate with their duties and responsibilities". ${ }^{53}$ Hays Parks emphasizes the importance of the instructor and his/her knowledge of the law, but asserts that the individual soldier or officer receiving training is more important than the instructor and his/her training session. This approach is consistent with Sassòli's argument that the "individual to be convinced" matters in IHL training, ${ }^{54}$ and with Kuper's emphasis on tailoring IHL training to a soldier's rank and to the deployment situations they are likely to face. ${ }^{55}$ The "extreme circumstances" of armed conflict present challenges to effective training, as do the often indeterminate norms in which soldiers are trained. ${ }^{56}$

In the second strand, scholars draw a sophisticated link between IHL training and behavioural change. Kuper defines learning with reference to the behaviour required for compliance: "a relatively permanent change in behaviour that occurs as a result of practice or experience." 57 This emphasis on practical learning is found in Françoise Hampson's 1989 article, where she emphasized that IHL training should be partly discursive, and should involve moral dilemmas which soldiers encounter in practical exercises, so that these dilemmas can be lawfully addressed "in the chaos of conflict." first century works on battle inoculation training at distributed simulation sites (training sites designed to emulate the challenges of deployment), ${ }^{59}$ on integrating IHL in computer games as a tool of IHL dissemination to civilians, and to future and current soldiers, ${ }^{60}$ and in quasiexperimental studies on moral competence training in the Swiss armed forces. ${ }^{61}$ This shows a cyclical relationship between some of the themes in the earlier literature and more recent innovations in approaches to compliance. Perhaps as a result of these innovations, Sassòli believes that prevention, dissemination and training "have made spectacular progress in recent years." $"$ If the current consultative stages of the Strengthening Compliance Initiative yield State reporting and/or separate thematic discussions on the domestic implementation of IHL, it might be possible to measure this progress, on IHL training specifically and on IHL compliance more generally, especially if reports and discussions are research-led. .

\footnotetext{
${ }^{52}$ W. Hays Parks, "Teaching the Law of War: A Reprise", Israel Defense Forces Law Review, Vol. 3, 2007, pp. 9,23 .

${ }^{53} \mathrm{CCW}$, Art. 6, above note 1, Amended Protocol II, Art. 14(3), cited by W. Hays Parks, ibid.

${ }^{54}$ M. Sassòli, above note 6.

${ }^{55}$ J. Kuper, above note 7, p.173.

${ }^{56}$ Ibid, p. 174.

${ }^{57}$ Ibid, pp.173-4.

${ }^{58}$ F. Hampson, above note 6, p.116.

59 Jon Saltmarsh and Sheena MacKenzie, "The Future of Collective Training: Mission Training through Distributed Simulation" RUSI Defence Systems, Royal United Services Institute, October 2008, pp. 107-110; Heather M. McIntyre, Ebb Smith and Mary Goode, "United Kingdom Mission Training Through Distributed Simulation" Military Psychology, Vol. 25, No. 3 2013, pp.280-293. Victoria Basham, War, Identity and the Liberal State: Everyday Experiences of the Geopolitical in the Armed Forces Routledge, London, 2013, p.30.

There is a greater emphasis on the skills to be gained in distributed simulation than in the potential to integrate IHL through distributed simulation training.

${ }^{60}$ Ben Clarke, Christian Rouffaer and François Sénéchaud, "Beyond the Call of Duty: Why Shouldn’t Video Game Players Face the Same Dilemmas as Real Soldiers?" Vol. 94 No.886 International Review of the Red Cross, pp.711-737.

61 Stefan Seiler, Andreas Fischer and Sybille A. Voegtli, "Developing Moral Decision-Making Competence: A Quasi-Experimental Intervention Study in the Swiss Armed Forces" Vol. 21, No. 6 Ethics \& Behavior, 2011,pp. 452-470.

${ }^{62}$ Marco Sassòli, "IHL Mechanisms in Armed Conflict: Where is the Problem?”, 36th Round Table on Current Issues in International Humanitarian Law, San Remo, 5-7 September 2013, p.2.
} 
Norm internalisation is a third theme. The South African military manual calls for the internalisation of IHL norms, so that they become second nature. ${ }^{63}$ While there is an educational dimension, focusing on the repetition of IHL rules in training, this meaning of "internalisation" echoes Finnemore and Sikkink's sense of the term, where after norms have "cascade[d]" from a few States to become widespread, they then become "taken-for-granted norms", no longer worthy of debate. ${ }^{64}$ In the IHL training context, it is sub-state actors (soldiers and officers) or members of armed groups who are internalising norms until they are "taken-for-granted."

Fourth, the relevance of group culture and communities of practice: Lloyd Roberts' "barracks culture" refers to one of the risks to IHL training programmes: he hints at the importance of social psychology from his own experience as a trainer in the British armed forces. Barracks culture may cause an "adjust[ment]" of the IHL disseminated to soldiers in their training: ${ }^{65}$ Lloyd Roberts reports that in his experience, this is a particular danger, in detention in the so-called "war on terror", ${ }^{66}$ although there is no inkling as to why social psychology should be more important in this context than in other deployments. Lloyd Roberts also mentions that IHL training is rarely perceived as a priority: "It is a brave commandant who insists on maintaining a module on the law of war. ${ }^{, 67}$ Murphy and Kuper echo these concerns, with reference to competing pressures on officers. ${ }^{68}$ These competing pressures might show something else: the influence of epistemic communities or communities of practice within the military, valuing IHL training to a greater or lesser extent.

Dickinson, in contrast, uses organisational psychology to explain the influence of the US Judges Advocate General (JAG) in promoting compliance with IHL. Dickinson argues that the US JAG corps could promote compliance by influencing the cultural norms in the military community: "fostering greater compliance" can be achieved not by new treaty norms, but instead by "subtly influencing organizational structures and cultural norms". 99 These structures and norms are neither IHL nor formal instruction in military ethics: they are closer to the "barracks culture" which Lloyd Roberts considers influential or the epistemic communities or communities of practice in constructivist literature. Dickinson argued that the "commingling" of JAG officers and soldiers is consistent with organisational theory and promotes compliance. This is despite the massacre at Haditha, where 24 civilians were killed by U.S. Marines, and judges advocate general did not report violations. ${ }^{70}$ Arguably, Dickinson's optimism about the potential of the JAG corps as agents of compliance does not engage sufficiently with the institutional failings revealed by the Haditha massacre.

\section{Interdisciplinary Work}

\footnotetext{
${ }^{63}$ Republic of South Africa, Military Manual, cited in ICRC Customary IHL Study, above note 2, Rule 142, p.503, footnote 45 .

${ }^{64}$ Martha Finnemore and Kathryn Sikkink, "International Norm Dynamics and Political Change", International Organization, Vol. 52, No. 4, 1998, pp. 887-917, 895.

${ }^{65}$ D. Lloyd Roberts, above note 49, p. 126.

${ }^{66} \mathrm{Ibid}$.

${ }^{67}$ Ibid, p. 125.

${ }^{68}$ Ray Murphy, "International humanitarian law training for multinational peace support operations - lessons from experience", International Review of the Red Cross, Vol. 82., No. 840 2000, pp. 953-968; J. Kuper, above note 7, p. 173.

${ }^{69}$ L. Dickinson, above note 8, p.3.

${ }^{70}$ Ibid, p. 26.
} 
There are hints in the literature that IHL training needs to take place in a context which facilitates the development of conscience: that ethics should be an integral part of IHL training, for example. ${ }^{71}$ Yet the body of work on IHL training appears to have developed in parallel to the more copious material on military ethics and social psychology in armed conflict. ${ }^{72}$ There is little systematic engagement with the advantages and disadvantages of integrating IHL and military ethics training in particular.

"Military ethics" does not have a settled international definition, and can be pliable. Some armed forces prefer an improvised definition of military ethics, which reflects an Army's broader cultural ethos while rejecting specific intellectual roots; ${ }^{73}$ others see Aristotelian phronesis (or practical wisdom) as the root of military ethics. ${ }^{74}$ A few ethicists seek to integrate a "critical understanding of the law of armed conflict" within their definition military ethics, alongside the unquantifiable "courage and spirit". ${ }^{75}$ If military ethics includes mandatory compliance with IHL, and reinforces the obligation to disobey an unlawful order, then it is useful to integrate training in ethics and law. However, the pliability of military ethics could present a threat to soldiers' internalisation of IHL norms, if they identify an antilaw ethos within their organisational culture.

The literature on military ethics training has at least two principal debates: first, whether training is capable of instilling ethical conduct, and second, whether military ethics training should train soldiers in independent reflection, given the importance of group cohesion and the command chain. As to the first, while Socrates reasoned that education alone is insufficient to produce virtue ${ }^{76}$ modern literature shows the potential of military ethics training, provided that (as for the IHL training context) there is a practical, reflective component, instead of dry classroom instruction. ${ }^{77}$ Lovell is more sceptical: ethics and empathy are "partly a function of cognitive development and not simply of education"78 but that education itself is too distanced from the "stress, grief and rage" of the battlefield to be sufficient to instil compliance. ${ }^{79}$ Van Baarda agrees: "moral competence" cannot be trained formally in a discrete session of classroom instruction, but that instead it is an ongoing personal chronology of learning, or an éducation permanente ${ }^{80}$ This scepticism contrasts with the empirical findings of Wortel and Bosch, showing a beneficial impact of ethics in a "train the trainers" scheme in the Netherlands armed forces. ${ }^{81}$ Their study shows the value of a mentoring or "train the trainers" approach (at least in military ethics), and could offer transferable insights for the design of IHL training.

\footnotetext{
${ }^{71}$ M. Sassòli, above note 6, p.73; D. Lovell, above note 9.

${ }^{72}$ A. Bandura, above note 8; J.-J. Frésard and D. Muñoz-Rojas, above note 10; ; P. Robinson, N. de Lee and D. Carrick (eds), above note 9.

${ }^{73}$ Stephen Deakin, "Education in an Ethos at the Royal Military Academy Sandhurst" in Robinson, de Lee and Carrick (eds), above note 9, p.15; Patrick Mileham, "Teaching Military Ethics in the British Armed Forces", in Robinson, de Lee and Carrick (eds), ibid., p.43.

${ }^{74}$ Martin L. Cook, "Ethics Education, Ethics Training and Character Development: Who 'Owns' Ethics in the US Air Force Academy” in Robinson, de Lee and Carrick (eds), p.57.

${ }^{75}$ M.L. Cook and H. Syse, above note 9, pp. 120, 121.

${ }^{76}$ Plato, Meno, trans. Benjamin Jowett, Liberal Arts Press, New York, 1949.

${ }^{77}$ John Keegan, The Face of Battle, Viking Press, New York, 1976, reprint Folio, London 2007, cited by D. Lovell, above note 9, p.146, footnotes 14-17.

${ }^{78}$ D. Lovell, above note 9, p.142.

${ }^{79}$ Ibid, p. 146 .

${ }^{80}$ Th.A. van Baarda, "Moral Ambiguities Underlying the Laws of Armed Conflict: A Perspective from Military Ethics", Yearbook of International Humanitarian Law, Vol. 11, 2010, pp.3, 39.

${ }^{81}$ Eva Wortel and Jolanda Bosch, "Strengthening Moral Competence: A 'Train the Trainer Course in Military Ethics", Journal of Military Ethics, Vol. 10, No.1, 2011, pp.17-35.
} 
A second debate on military ethics parallels the competing priorities which might squeeze out IHL training. Moseley suggests that the command chain is not always in favour of instruction programmes that might encourage independent thought. ${ }^{82} \mathrm{He}$ argues that commanding officers should accept that military ethics instruction encourages "unlimited criticality." ${ }^{\prime 3}$ The British armed forces opt for what Robinson, de Lee and Carrick term a "pragmatic" approach, in which an "ethos", not ethics, is "caught", not taught. ${ }^{84}$ If this is an accurate reflection of modern practice it leaves too much to chance. The IHL training literature emphasizes attitudinal change and the internalisation of norms, while considering that a barracks culture which is antagonistic to IHL compliance is a risk for that norm internalisation. If military ethics training is improvised, or if the command chain is opposed to the independent thought that military ethics training might encourage, as Moseley argues, the barracks culture is less likely to support the internalisation of IHL norms. Those researching IHL training would benefit from a thorough synthesis of the literature on military ethics, while recognizing that flexible principles can never replace norm internalisation in IHL.

While military ethics emphasizes the moral development of the individual soldier or officer, recent work in the social psychology of conflict shows the influence of the group. It is this research that adds depth to the concept of Lloyd Roberts" "barracks culture" and to communities of practice in the military. The 2004 Roots of Behaviour in War Study surveyed former fighters in Bosnia-Herzegovina, Colombia, the Republic of the Congo (Congo-Brazzaville) and Georgia for the ICRC, and found no positive correlation between moral disengagement and ignorance of the law: attitudes associated with a risk of violations were held by some fighters who had a good knowledge of the law. ${ }^{85}$ The research indicated that fighters' willingness to disregard IHL is linked to moral disengagement, which has two dimensions: a) the justification of violations by a fighter's own group (which in turn correlates with group cohesion), and b) the dehumanising of the enemy. ${ }^{86}$ The authors found that "What counts is esteem for their comrades, defence of their collective reputation and desire to contribute to the success of the group." ...responsibility...induced chiefly by group conformity and obedience to orders.", 88

The group cohesion that Muñoz-Rojas and Frésard implicated in moral disengagement by former fighters is an explicit aim of military training, so that soldiers fight for other members of their unit and respect the command chain. Training in IHL and training for conformity and group cohesion may work antagonistically, as Bourke and Shalit have noted, among others. Harnessing group cohesion to IHL compliance, by expressly relating IHL compliance to the honour of the regiment would be one way of taking account of these findings. Further synthesis could be achieved by acknowledging Muñoz-Rojas and Frésard's finding that IHL training is not merely insufficient to induce compliance, but that it could be "counter-productive where mechanisms of moral disengagement are present." ${ }^{\text {" }}$ Addressing moral disengagement is logically prior to instruction in IHL on this reading. Yet the survey

\footnotetext{
${ }^{82}$ Alexander Moseley, “The Ethical Warrior: A Classical Liberal Approach”, in P. Robinson, N. de Lee and D. Carrick (eds) above note 9, pp.175-186.

${ }^{83}$ Ibid.

${ }^{84}$ P. Robinson, N. de Lee and D. Carrick (eds), above note 9, Introduction; Ibid., Patrick Mileham, "Teaching Military Ethics in the British Armed Forces", pp.43-56.

${ }^{85}$ D Muñoz-Rojas and J.-J. Frésard, above note 10.

${ }^{86}$ Ibid, p.197.

${ }^{87}$ Ibid, p. 194

${ }^{88}$ Ibid, p. 190.

${ }^{89}$ Ibid, p. 200.
} 
data was not resoundingly sceptical. Provided that there was no group influence seeking to justify violations of IHL, Muñoz-Rojas and Frésard found that IHL knowledge had "a moderating effect on the spiral of violence", apparently preventing a cycle of revenge. ${ }^{90}$

These nuanced, empirical findings were from samples of former fighters in four conflicts, and therefore have a degree of external validity or generalizability, but as the ICRC has noted, it is time to re-evaluate the findings of this decade-old study. The literature on IHL training merely hints at the importance of interdisciplinary reflections, and provides an array of tips on best practice.

This article has begun to synthesize the academic and practitioner reflections on IHL training, and the interdisciplinary works which explore the conundrum between IHL training and subsequent compliance. Academic and practitioner insights lend themselves to a rubric on State practice in IHL training which addresses the educational approach, how behavioural change is assessed, how States approach soldiers' and officers' norm internalisation, and any risks to IHL compliance from military culture in their particular context. Interdisciplinary insights emphasise the necessity but insufficiency of IHL training for future compliance, and suggest that States might usefully share insights on how to prevent moral disengagement in the chaos of the battlefield where IHL compliance is imperative. The next section considers the ICRC's progression from dissemination of the law to its integration in military decisionmaking, and to its broader work on the prevention of violations.

\section{From Dissemination to Integration, and to Prevention: the ICRC's Approach}

Over the past two decades, the ICRC has gradually shifted its IHL activities to armed forces and armed groups from simple dissemination of the law to an emphasis on integration. ${ }^{91}$ Integration has had two main outputs: firstly the idea that IHL should be integrated into all aspects of "doctrine, training, education, equipment and sanctions" 92 and more recently that IHL is continuously relevant to the decision-making and communication within the military command structure. ${ }^{93}$ The first was a promising work-in-progress for increasing the effectiveness of IHL training. More recently, integration has become a comprehensive compliance tool, which is operationally relevant, taking account of the real-time challenges of intelligence and targeting.

The first approach to integration involves a "continuous process", in which IHL becomes relevant to "doctrine, training, education, equipment and sanctions." 94 Importantly, integration includes training, but is not just training. Integration requires the prior interpretation of the law, an understanding of its operational consequences, and the adoption of "concrete measures...to permit for compliance during operations." 95 In recognising that IHL training alone is insufficient for compliance, the ICRC acknowledges that "the mere teaching of legal norms will not result, in itself, in a change in attitude or behaviour", 96

\footnotetext{
${ }^{90}$ Ibid, p.201.

${ }^{91}$ ICRC, "Integrating the Law", above note 13.

${ }^{92}$ Ibid; ICRC, "Violence and the Use of Force", above note 13, p.58. An earlier hint of "integration" appears in Dietmar Klenner, "Training in International Humanitarian Law" International Review of the Red Cross, Vol. 82, No. 839, 2000,pp. 653-662, 656, 659, 660-661.

${ }^{93}$ ICRC, "Decision-making Process in Military Combat Operations", above note 14.

${ }^{94}$ ICRC, "Violence and the Use of Force", above note 13, p.58.

95 Ibid.

${ }^{96}$ Ibid.
} 
reflecting the interdisciplinary scholarship on IHL training. The integration model emphasizes IHL's continued relevance when soldiers and officers learn about a new weapons system, so that they can learn whether it can be used lawfully in civilian areas, or whether it can cause superfluous injury or unnecessary suffering. Furthermore, an integration of IHL training with an understanding of military discipline and international criminal law should reduce misconceptions about international law, ${ }^{97}$ which in turn could increase IHL compliance among service personnel.

The ICRC's more recent document on integration addresses the continuous application of IHL: compliance-in-progress in the command chain and during armed conflict. ${ }^{98}$ In this new formulation, integration is beginning to close the gap between historic treaties' emphasis on giving "instructions" (orders) consistent with $\mathrm{IHL}^{99}$ and the assumption from the Four Geneva Conventions and the Pictet Commentary (1952-1960) that dissemination and military instruction in IHL would help "ensure respect" for the law. This approach emphasizes ongoing communication about IHL throughout the command chain. ${ }^{100}$ This author will read with interest the pending Updated Commentary to the Four Geneva Conventions (due in consecutive years from 2015-2019), to see how integration and the Roots of Behaviour in War Study's findings might be reflected in a more sophisticated understanding of the dissemination and training obligation.

In relation to IHL training, it is the commander's responsibility to verify subordinates' knowledge of the law, moving away from the "train the trainers" delegation of the IHL training obligation and towards a process of ongoing internal evaluation of IHL training. ${ }^{101} \mathrm{In}$ contrast to the group cohesion and risk of justification of unlawful orders which MuñozRojas and Frésard found in their sample, integration should allow soldiers the opportunity to clarify the lawfulness of a mission or specific order, "if time and situation permit". ${ }^{102}$ This disrupts concepts of conformity and unthinking obedience to the chain of command, and strongly endorses the legal obligation only to carry out lawful orders. Integration also emphasizes the continuous nature of IHL obligations, with reference to targeting, precautions and logistics: IHL is relevant to decision-making throughout an attack, not merely when a target is first selected, so that commanding officers must clarify and information gaps which might affect IHL compliance, ${ }^{103}$ and must desist from any attack from the moment that intelligence suggests it will be indiscriminate or disproportionate. The lawfulness of targeting must be kept under "constant review". ${ }^{104}$ While integration is thoroughly pragmatic and there is no explicit reference to theoretical work, the ICRC's emphasis on continuous communication happens to be well-grounded in constructivist compliance theory, where theorists ranging from Lon Fuller to Brunée \& Toope emphasize ongoing communication in expert communities as a means of improving compliance with the law. ${ }^{105}$ The integration

\footnotetext{
${ }^{97}$ W. G. L. Mackinlay, "Perceptions and Misconceptions: How are International and UK Law Perceived to Affect Military Commanders and Their Subordinates on Operations?", Defence Studies, Vol. 7, 2007, pp.111160.

${ }^{98}$ ICRC, "Decision-making Process in Military Combat Operations", above note 14.

${ }^{99}$ Convention IV respecting the Laws and Customs of War on Land (Hague Convention IV) 18 October 1907, (entered into force 16 January 1910), Art. 1.

${ }^{100}$ ICRC, "Decision-making Process in Military Combat Operations", above note 14, pp.22, 24.

${ }^{101}$ Ibid, p. 22 .

${ }^{102}$ Ibid, p.43.

${ }^{103}$ Ibid, p. 18 .

${ }^{104}$ Ibid, p.31.

${ }^{105}$ Jutta Brunée and Stephen J. Toope, Legitimacy and Legality in International Law: An Interactional Account Cambridge University Press, Cambridge, 2010, pp.16, 62.
} 
approach has in effect progressed from a way of improving the effectiveness of IHL training to a comprehensive operationally-relevant compliance mechanism.

The ICRC's "prevention" strand is broader than its work on the integration of IHL, but it remains practical and grounded in interdisciplinary evidence. Differentiated from "protection", "assistance", and "cooperation", prevention "aims to foster an environment conducive to the respect for the life and dignity of persons" affected by armed conflict and violence; and to ensure that armed actors respect the ICRC's role. ${ }^{106}$ Since the publication of the Roots of Behaviour in War study, the ICRC has broadened its prevention work, which now includes the identification of appropriate stakeholders to create and maintain national legislation, sanctions and reparations to implement IHL; and dialogue with armed forces, armed groups, government officials, academia and civil society to promote IHL compliance and to reduce public discourse which might encourage violations of the law. ${ }^{107}$ This varied interdisciplinary toolkit recognizes the insufficiency of mere dissemination of IHL, but includes integration of the law in military training and decision-making.

While the ICRC's prevention toolkit is broad and the second iteration of integration qualitative and communicative, the integration of IHL training in doctrine, education, equipment and sanctions could be usefully added into a rubric for States to share their IHL dissemination and training activities. These criteria would be more informative than a simple "tick-box" approach, where States merely report that military training in IHL does take place. The next section considers the potential outcomes of the ICRC/Swiss initiative on Strengthening Compliance with IHL, which is in its consultation phase until December 2015.

\section{The Initiative on Strengthening Compliance with IHL led by the ICRC and the Government of Switzerland}

At the time of writing, the ICRC and the Government of Switzerland are leading a major consultative process on Strengthening Compliance with International Humanitarian Law. This process was established in Resolution 1 of the 31 st International Conference of the Red Cross and Red Crescent in 2011, which:

"...invites the ICRC to pursue further research, consultation and discussion in cooperation with States and, if appropriate, other relevant actors, including international and regional organizations, to identify and propose a range of options and its recommendations to: i) ensure that international humanitarian law remains practical and relevant in providing legal protection to all persons deprived of their liberty in relation to armed conflict; and ii) enhance and ensure the effectiveness of mechanisms of compliance with international humanitarian law, and encourages all members of the International Conference, including National Societies, to participate in this work while recognizing the primary role of States in the development of international humanitarian law". 108

The Initiative proceeds from the basis that existing mechanisms in the Geneva Conventions and Additional Protocol I (such as Protecting Powers and the International Humanitarian Fact-Finding Mission) are not used, and no compliance processes exist in the IHL of non-

\footnotetext{
106 ICRC, ICRC Prevention Policy, Geneva, 11 June 2010, Publication Ref. 4019, p.5, available at: https://www.icrc.org/eng/resources/documents/publication/p4019.htm.

${ }^{107}$ Ibid, p.9,

${ }^{108}$ Resolution 1, $31^{\text {st }}$ International Conference of the Red Cross and Red Crescent, 2011, available at: https://www.icrc.org/end/resources/documents/resolution/31-international-conference-resolution-1-2011.htm.
} 
international armed conflict. The Four Geneva Conventions and their Additional Protocols lack a reporting and monitoring mechanism, in contrast to the mechanisms relating to landmines, cultural property and children and armed conflict. ${ }^{109}$ The phrasing of Resolution 1: "invites", "encourages" illustrates the consensual and voluntary nature of any tools for compliance which might be agreed upon as part of the consultation process. There are no plans to revisit treaty texts: any mechanism that might be agreed will be non-binding. Meetings of States, voluntary reports on the implementation of IHL, and thematic discussions are among the mechanisms currently under discussion. ${ }^{110}$ If any of these are agreed, the $32 \mathrm{nd}$ International Conference of the Red Cross and Red Crescent will be the beginning of these initiatives.

Although any process agreed will be voluntary and non-binding, the agenda of the Strengthening Compliance initiative is ambitious. While early meetings seem to have removed from the agenda discussions of legal opinions, country visits, urgent appeals and an early warning function, ${ }^{111}$ consultations have moved forward on periodic reporting, although discussions on fact-finding have been postponed until an institutional structure can be established. ${ }^{112}$ Delegates are keen to avoid both politicization ${ }^{113}$ and excessive use of resources. ${ }^{114}$ Discussions on any involvement of non-state actors, as a means of improving compliance in non-international armed conflicts will await the conclusion of the consultation phase. A review of the documents available to date shows politicization is an important concern: state delegates would prefer a "non-contextual and non-conflict specific basis" to the discussions. ${ }^{115}$

On the one hand, the options available to the Strengthening Compliance Initiative's emphasize discussion and the sharing of practices. In the author's view, this is consistent with modern, sophisticated approaches to IHL compliance, which show that simply disseminating IHL is insufficient to ensure respect for the law. On the other hand, the consensus-building approach has favoured a broad, perhaps superficial, approach to IHL compliance. The current consultation process has no decision-making power, but a Meeting of States has been supported as a "central pillar" of compliance initiatives, and "most States" agree that voluntary reporting on national practice in IHL, and a separate process for thematic discussion "should be established". A fact-finding mechanism might be "added over time if there is State agreement". ${ }^{116}$ Views differ on whether or not civil society observers should be invited to the meetings of States, with some delegations opposing this as they fear the meetings might be "politici[zed]". All views expressed are unattributed to particular States. ${ }^{117}$

\footnotetext{
${ }^{109}$ ICRC and Government of Switzerland, Background Document: Working Group Meeting on Strengthening Compliance with IHL, 8-9 November 2012, Geneva, October 2012. See also: ICRC and Government of Switzerland, Background Document: Fourth Meeting of States on Strengthening Compliance with IHL, Geneva, March 2015. All documents on the Initiative are available at: https://www.icrc.org/eng/what-we-do/otheractivities/development-ihl/strengthening-legal-protection-compliance.htm.

${ }^{110}$ ICRC and Government of Switzerland, Third Meeting of States on Strengthening Compliance with International Humanitarian Law (IHL), 30 June-1 July 2014, Chairs' Conclusions, (Third Meeting of States, Chairs' Conclusions) See also, ICRC and Government of Switzerland, Preparatory Discussion in View of the Fourth Meeting of States (2015), December 2014.

${ }^{111}$ Background Document, above note 109, pp.17-18.

112 Third Meeting of States, Chairs' Conclusions, above note 110, pp.2, 5.

${ }^{113}$ Ibid, pp.8, 10, 13.

${ }^{114}$ Ibid. p.3.

115 Ibid. p.4.

${ }^{116}$ Background Document: Fourth Meeting of States, above note 109, p.6.

117 Third Meeting of States, Chairs' Conclusions, above note 110, p.13.
} 


\section{Towards a Rubric for State Reporting on Military Training in International Humanitarian Law}

The pending Strengthening Compliance Initiative has not yet considered in depth the potential impact of academic research. The discussion in this article is advanced as a set of insights which States and the ICRC might bear in mind as discussions continue. In particular, if a State reporting mechanism is agreed, a rubric which synthesizes academic and practitioner research on IHL training and compliance could help States avoid a simple, superficial approach to reporting their practice in relation to military instruction in IHL: a flaw found in some State reports in the Compliance Mechanism established under the $\mathrm{CCW} .{ }^{118}$ Enriched, substantive discussion is appropriate for any voluntary mechanism which might be agreed by the Strengthening Compliance Initiative. Research-led parameters could enable more fruitful sharing of best practice and new innovations as they evolve. An informative template for State reports could also address States' concerns about the costs and administrative burden of preparing State reports, as reports prepared under this rubric would be standardized and the process streamlined.

The analysis above suggests that a rubric for state reports on effective IHL training might include the following questions, each of which might be usefully discussed at a collaborative workshop of states, researchers and ICRC representatives prior to being agreed:

1. What are the educational approaches adopted to instruct members of the armed forces in IHL? Are these predominantly classroom-based, or a blend of classroom and practical instruction? How are these adapted to soldiers' rank and the range of situations they are likely to face? How is literacy taken into account?

2. How does IHL instruction address future behaviour on operations? Does IHL instruction for officers include the discussion of scenarios? Is IHL instruction supplemented by the use of technology, and/or by distributed simulation sites?

3. How is norm internalisation addressed? What evaluation tools are used within the state to test soldiers' recall and understanding of IHL norms?

4. How does military culture and/or broader media discourse influence personnel's willingness to comply with the law?

5. To what extent is IHL integrated in "doctrine, education, equipment, training and sanctions" and to military decision-making throughout the command chain?

\section{Next Steps for Qualitative and Empirical Research}

Interdisciplinary research is not currently included in this suggested rubric, but it can alert States to the risks of moral disengagement, false justifications of violations, and a misunderstanding of reciprocity undermining otherwise well-designed IHL training. As a next step, interdisciplinary researchers might find and test mechanisms which instil a good knowledge of IHL and a resistance to moral disengagement or justifications of unlawful conduct. At a later date, this author plans to conduct surveys and interviews of soldiers and officers in the British Army to ascertain their understanding of IHL and their attitudes towards compliance. Other researchers might test the impact of distributed simulation

\footnotetext{
${ }^{118}$ United Nations Office at Geneva (UNOG), The Convention on Certain Conventional Weapons, Compliance Annual Reports Database, available at: http://www.onug.ch/80256EE600585943/(httpPages)/E0339F1FE92C35FBC12573E900351CD5?OpenDocume nt.
} 
environments on soldiers' practical internalisation of IHL norms, as compared to dry, classroom instruction in IHL. More qualitative researchers might attempt to understand the impact of barracks culture and communities of practice on the design and implementation of IHL training, and to feed back their findings to military lawyers who organize IHL training programmes. There are ethical constraints on researchers who are "embedded" with the military or otherwise might be perceived as instruments of an armed force instead of independent researchers. It is imperative that each of these studies be fully consistent with Universities' and funding bodies' ethics review criteria, and that military interlocutors allow researchers to conduct their work without vetting the substance of their analysis prior to publication.

For different ethical reasons, quasi-experimental methods have a more limited role in testing the effectiveness of military IHL training. ${ }^{119}$ Given the importance of IHL compliance, it would be unethical to divide soldiers between an experimental group which receives a form of IHL training thought to be effective, while another, control group receives an incomplete or rudimentary form of IHL instruction. However, quasi-experimental studies which compare already-present differences in practice (e.g. between regiments or different training sites) would not present these ethical concerns. Quasi-experimental studies might show the influence of barracks discourse on IHL survey responses more clearly than interview data. These studies would form part of the burgeoning literature which applies empirical or political science method to international law. ${ }^{120}$ With appropriate ethical approval, these methods are ideally suited to studying the influence of IHL training on arms carriers' capacity and willingness to comply with the law, and the risks of barracks culture or discourses of "othering" that might undermine IHL training. A rigorous interdisciplinary approach will bring the body of literature on IHL training to maturity.

\section{Conclusion}

The dissemination of international humanitarian law and its integration in programmes of military instruction and training were once assumed idealistically to promote compliance with and prevent violations of the law. While ignorance of IHL is one among several contextual factors found where violations lead to courts-martial or public inquiries, IHL training is necessary but insufficient to ensure respect for international humanitarian law. The treaty norm itself is simply stated and discretionary, giving little guidance to States on best practices in IHL training. Academic and practitioner reflections on IHL training built theory interstitially, with works emphasising the importance of individual conscience, ethics, and mission-specific flexibility, and for the need for repetition so that norms were internalized as second nature. These reflections were published in parallel to more numerous works on military ethics and social psychology in armed conflict, which showed inter alia that the aims of military training (to desensitize soldiers to killing, to create unquestioning obedience to the command chain, to consider enemy forces as "other") were antagonistic to the aims of

\footnotetext{
${ }^{119}$ Contrast the view of Adam S. Chilton and Dustin H. Tingley, "Why the Study of International Law Needs Experiments" Columbia Journal of Transnational Law, Vol. 52, No.1, 2013, p.173.

${ }^{120}$ Gregory Shaffer and Tom Ginsburg, "The Empirical Turn in International Legal Scholarship" American Journal of International Law, Vol. 106, No.1, 2012, p. 1.
} 
training in IHL. ${ }^{121}$ Only recently have interdisciplinary studies shown that knowledge of the law and attitudes consistent with a risk of violations can occur together. ${ }^{122}$

The ICRC has evolved a theory of integration, firstly a notion that IHL be interpreted and then recur throughout a soldier's training and education cycle, being relevant to doctrine, equipment and sanctions; ${ }^{123}$ and secondly, that IHL be integrated throughout the communicative structure of the military command chain. ${ }^{124}$ The law requires that the stereotype of unthinking obedience to superior orders must be disrupted where there is doubt as to the lawfulness of an order; under the integration model, it must be possible for soldiers to clarify the lawfulness of an order with their commanding officer. Integration also emphasizes the continuous nature of IHL obligations, with reference to targeting, precautions and logistics: IHL is relevant to decision-making throughout an attack, not merely when a target is first selected. In integration, law is continuously relevant to operations and military decision-making, so IHL training cannot be a single, discrete classroom session on the Geneva Conventions. Integration shows real promise as a comprehensive compliance strategy for IHL, and fits within the ICRC's broader work on prevention.

The ongoing ICRC/Swiss initiative on Strengthening Compliance with IHL is a separate development, and a range of possible voluntary processes is being discussed, including thematic reports, periodic State Party reports, and regular meetings of States. ${ }^{125}$

This article has synthesized academic and practitioner reflections on effective IHL training, and has argued that research can inform criteria for state reporting on IHL training, if voluntary reports are agreed as a mechanism to strengthen compliance with IHL. The article has suggested a rubric for State reports on effective military instruction in IHL, as a means of avoiding a "tick-box" exercise, while simultaneously addressing States' resource concerns. The suggested rubric would benefit from workshop discussion with representatives of States and the ICRC. To summarize, a rubric would bring state practice towards effective military training in IHL in two ways: first, the rubric would share research on IHL training with States, synthesising insights which are currently scattered in the literature; and second, it would enable states to share best practice and future innovations on military training, using a streamlined, cost-effective tool.

Interdisciplinary research can inform policy-makers of the limits and potential of IHL training, and can add substantive depth to thematic discussions, if these are adopted by the Strengthening Compliance Initiative. Instead of simply acknowledging that IHL training is necessary (if insufficient) for compliance with the law, it is time to test its effectiveness, and to build mechanisms that facilitate best practice.

\footnotetext{
${ }^{121}$ R. Holmes, B. Shalit, and J. Bourke, above note 12.

${ }^{122}$ D. Muñoz-Rojas and J.-J. Frésard, above note 10.

${ }^{123}$ ICRC, "Integrating the Law", above note 13.

${ }^{124}$ ICRC, "Decision-making Process in Military Combat Operations", above note 14.

${ }^{125}$ Third Meeting of States, Chairs' Conclusions, above note 110.
} 